\title{
TIMBER MANAGEMENT PRACTICES AND TIMBER SPECIES USED BY SMALL SCALE FURNITURE WORKSHOPS IN UGANDA
}

\author{
O. E. Sseremba ${ }^{1}$, J. R. S. Kaboggoza ${ }^{1}$, N. Y. Ziraba ${ }^{2}$, P. Mugabi, A. Y. Banana ${ }^{1}$, A. Zziwa ${ }^{1}$, \\ R. K. Kambugu' ${ }^{1}$, S. Kizito ${ }^{1}$, A. Syofuna ${ }^{1}$, J. Ndawula
}

\begin{abstract}
A study was done in Kampala District, Central Uganda, to document the timber species and timber management practices used in furniture workshops. A check list was used to document the common timber species, their grades, moisture contents and related timber management practices in furniture workshops. Results showed that Albizia coriaria,Markhamia lutea and Chrysophyllum albidum were the most common species while Khaya spp, Milicia excelsa and Olea spp were the least used species in the furniture workshops. Sixty nine percent of the furniture workshops lacked timber storage sheds, whereas only $3 \%$ had the recommended timber stacks. Majority (95\%) of the carpenters in the furniture workshops did not season timber and hence the moisture content of the timber ranged from $31 \%$ to $35 \%$. Forty nine percent of the workshops exposed their finished products to environmental and weather deterioration. The commonest type of wood waste was planer shavings which were not utilised effectively. Since $97 \%$ of carpenters did not grade timber, the quality of their products was inherently poor. The study concluded that several lesser known timber species were used for making furniture amidst very poor timber management. The study recommends that the government of Uganda through its policyimplementing arms should create awareness programmes to carpenters on efficient timber management practices. Further research on physical, processing and strength properties of the documented species should be undertaken so as to improve their utilisation.
\end{abstract}

Keywords: Carpenters, furniture, species, timber and workshops

\section{INTRODUCTION}

The world trends in economic development have led to increased demand for wood as a construction raw material. The Department of Statictics-Malysia (DSM 2002) estimated the rise in the world wood demand to be from 200 million cubic metres in 1991 to 313 million cubic meters by the year 2010. For Africa, a 34\% increase in the demand for wooden furniture products by the year 2010 was projected. This implies that developing countries like Uganda whose wooden furniture industries are characterised by inefficiencies will suffer increased deforestation. In addition, developing countries do not get value for wood material used since their timber products are of a lower quality and may not compete favourably with imported products. Unfortunately, improvement of product quality assurance in Uganda's furniture industry is made difficult owing to limited documentation and the present use of unguided timber management practices.

The increasing scarcity of the traditionally valuable timber species, has led to increase in demand for previously lesser used timber species (Zziwa et al. 2006a). In the context of this paper, traditionally valuable timber species are those that were preferred for use in the past three decades for specific

\footnotetext{
Department of Forest Products Engineering, Faculty of Forestry and Nature Conservation, Makerere University, P.O. Box 7062 Kampala, Uganda. sserembaowen@gmail.com

2 Department of Civil Engineering, Faculty of Technology, Makerere University, P.O. Box 7062 Kampala, Uganda.

Corresponding author: osseremba@forest.mak.ac.ug

Received: 30.10.2010 Accepted: 05.09.2011
} 
applications while lesser used timber species are those that were originally neglected and ignored for similar applications but are now opted for, due to reduced availability of alternative species (Mugabi 2002, Zziwa et al. 2006b). Some of the lesser used timber species that are now found in the small scale furniture workshops include; Mangifera indica and Artocarpus heterophyllus (Sseremba 2005), while the traditionally valuable timber species include; Khaya spp and Entandrophragma spp (Kityo and Plumptre 1997). To sustainably manage forests, the shifts in timber species use have to be monitored so that appropriate management regimes can be implemented. Part of the monitoring involves conducting studies on the lesser known timbers to improve their utilisation as substitutes for the scarce traditional species. This will eventually contribute to better and sustainable management of the forest estate in Uganda, in addition to achieving of the Millennium Development Goal number seven that advocates for sustainable environmental management (UN 2006).

There are a number of wooden furniture importers in Kampala and Uganda at large, as well as several small scale industries that locally produce as much furniture for low income earners. These small scale wooden furniture industries make up to $26 \%$ of the total number of manufacturing businesses in Uganda (UBOS 2002). Their activities include; solid wood processing for furniture, crafts and rattan processing, wood carving, panelling and furnishing. However, from a reconnaissance survey, it was found that there were several inefficiencies observed in the production of wooden furniture, such as limited timber seasoning, inappropriate waste management and utilisation, and poor product storage. This means that the furniture produced may not compete with higher quality imported furniture. In this situation, there is an increased dependency on imported furniture items that affect the country's economic growth. Therefore, the extent to which the poor practices and inefficient production in Uganda's wooden furniture industry should be considered as an urgent matter to be addressed and documented as it would enable to highlight the critical weaknesses in the system and recommend mitigation measures. Hence, a study was undertaken aiming to identify timber species utilised in the small scale furniture workshops and the timber management practices in the workshops.

\section{MATERIALS AND METHODS}

\section{Study area}

The study was carried out within Kampala district, the capital city of Uganda. The district has about $35 \%$ of the total number of furniture workshops in the country (UBOS 2002). It was selected because of its higher level of business activity, where most timber trade is done which made it a good focal point for the study. Four out of the five divisions of Kampala district were purposively selected. The fifth division, located in the central division had low levels of furniture activities. Twenty five workshops were selected from each of the four divisions which made a total of 100 workshops for the entire study. Furniture workshop managers and technical employees were interviewed. For each workshop, ten timber boards were randomly selected from the store for assessing their grade and moisture content according to the Uganda Timber Grading rules of 1967 (Tack 1967). The timber management practices that were assessed included: timber storage attributes prior to its use; seasoning methods; waste management and control; general workshop sanitation and finished product handling and storage. These were assessed by observation using an interview guide.

\section{Data Analysis}

Descriptive statistics were generated and used to obtain the percentage occurrence and use of each of the identified species in wooden furniture workshops. Timber species were grouped into: commonly used, new entrant (non traditional) and scarce. The frequency of a particular species occurrence was expressed as a percentage of the total. Ranking of the percentages obtained for each of the timber species was used to obtain the commonly used timber species. The magnitudes for the rankings were obtained by expressing the frequencies as a percentage of the total number of mentions of a given species by the carpenters, for a category of species. Frequencies of incidence and percentages of each of the timber management practices were obtained and documented. 


\section{RESULTS}

\section{Commonly Used Timber Species}

Twenty-five species were listed as commonly used (Table 1), fourteen as non traditional species (Table 2) while the scarce species were seven (Table 3). Antiaris toxicaria, Artocarpus heterophyllus and Mangifera indica were the most abundant species among the category of 'new entrant' species (Table 2 ) and were mostly used to make upholstery furniture frameworks.

Table 1. Commonly used timber species for making furniture.

\begin{tabular}{|c|c|c|}
\hline Trade name & Botanic name & Modal Rank $(\%) \mathbf{N}=\mathbf{8 1 8}$ \\
\hline Mvule & Melicia excelsa & 11.5 \\
\hline Mugavu & Albizia coriaria & 10.3 \\
\hline Musambya & Markhamia lutea & 9.7 \\
\hline Nkalati & Chrysophyllum albidum & 9.4 \\
\hline Mahogany & Khaya spp & 9.2 \\
\hline Pine & Pinus spp & 8.8 \\
\hline Nkoba & Lovoa trichiliodes & 6.6 \\
\hline Cypres & Cupressus lusitanica & 6.5 \\
\hline Musizi & Maesopsis eminii & 5.0 \\
\hline Namagulu & Musanga cecropioides & 4.2 \\
\hline Muwafu & Canarium schweinfurthii & 3.5 \\
\hline Nzingu & Hallea stipulosa & 2.9 \\
\hline Nkuzannyana & Blighia unijugata & 2.6 \\
\hline Nongo & Albizia spp & 2.3 \\
\hline Kirundu & Antiaris toxicaria & 2.2 \\
\hline Mukusu & Uapaca guineensis & 0.9 \\
\hline Mpewere & Piptadeniastrum africana & 0.9 \\
\hline Teak & Olea $s p$ & 0.7 \\
\hline Mukokoowe & Ficus ovata & 0.6 \\
\hline Eucalyptus & Eucalyptus spp & 0.5 \\
\hline Lufugo & Celtis mildbraedii & 0.4 \\
\hline Kasiisa & Trema orientalis & 0.4 \\
\hline Muyovu & Entandrophragma cylindricum & 0.4 \\
\hline Namukago & Funtumia africana & 0.2 \\
\hline Mumuli & Holoptelea grandis & 0.1 \\
\hline
\end{tabular}


Table 2. Non traditional timber species and their common uses.

\begin{tabular}{|l|l|c|l|}
\hline \multicolumn{1}{|c|}{ Trade name } & \multicolumn{1}{|c|}{ Botanic name } & $\begin{array}{c}\text { Modal Rank (\%) } \\
\text { N=578 }\end{array}$ & \multicolumn{1}{|c|}{ Common use } \\
\hline Kirundu & Antiaris toxicaria & 13.7 & Upholstery frames \\
\hline Ffene & Artocarpus heterophyllus & 12.1 & Upholstery frames \\
\hline Muyembe & Mangifera indica & 7.1 & Upholstery frames \\
\hline Kasiisa & Celtis zenkeri & 6.9 & Upholstery frames \\
\hline Mpewere & Piptadeniastrum africana & 5.5 & Cupboards and Tables \\
\hline Sadrela & Cedrella odorata & 5.4 & Upholstery frames \\
\hline Mutuba & Ficus natalensis & 5.2 & Upholstery frames \\
\hline Namagulu & Musanga cecropioides & 4.7 & Upholstery frames \\
\hline Mukokoowe & Ficus ovata & 4.5 & Upholstery frames \\
\hline Settaala & Polyscias ferruginea & 4.0 & Upholstery frames \\
\hline Musambya & Markhamia lutea & 4.0 & Tables, chairs and desks \\
\hline Cypres & Cupressus lusitanica & 3.3 & Cupboards and Tables \\
\hline Mugavu & Albizia coriaria & 3.1 & Beds \\
\hline Lufugo & Celtis mildbraedii & 2.8 & Tables, chairs and desks \\
\hline Muwafu & Canarium schweinfurthii & 2.8 & Shelves \\
\hline Nkuzannyana & Blighia unijugata & 0.9 & Tables, chairs and desks \\
\hline Muyovu & Entandrophragma spp & 0.9 & Tables, chairs and desks \\
\hline Nzingu & Mitragyne spp & 0.5 & Tables, chairs and desks \\
\hline Kabakanjagala & Aleurites moluccana & Upholstery frames \\
\hline
\end{tabular}

Table 3. Scarce timber species in furniture workshops.

\begin{tabular}{|c|c|c|}
\hline Trade name & Botanical name & Modal Rank (\%) N=327 \\
\hline Mahogany & Khaya spp & 29.1 \\
\hline Muvule & Melicia excelsa & 22.7 \\
\hline Teak & Olea spp & 22.1 \\
\hline Pine & Pinus spp & 9.8 \\
\hline Cypres & Cupressus lusitanica & 6.1 \\
\hline Nkoba & Lovoa trichiliodes & 5.5 \\
\hline Nongo & Albizia spp & 4.6 \\
\hline
\end{tabular}

Comparisons of changing uses of tree species over time based on the findings of this study and those of previous researchers are shown in table 4 
Table 1. Changes in Uses of Non-traditional Tree Species over Time.

\begin{tabular}{|c|c|c|c|}
\hline Trade name & Botanical name & Kityo and Plumptre (1997) & This study $(2008)$ \\
\hline Kirundu & Antiaris toxicaria & $\begin{array}{l}\text { Recommended for veneer and } \\
\text { plywood } \\
\text { Not recommended for timber } \\
\text { structural use }\end{array}$ & $\begin{array}{l}\text { Used for making shop } \\
\text { shelves and upholstered } \\
\text { furniture frames }\end{array}$ \\
\hline Ffene & Artocarpus heterophyllus & Not known then & $\begin{array}{l}\text { Used for framings of } \\
\text { upholstered furniture }\end{array}$ \\
\hline Muyembe & Mangifera indica & $\begin{array}{l}\text { Not known for timber, Known as } \\
\text { fruit tree }\end{array}$ & $\begin{array}{l}\text { Used for framings of } \\
\text { upholstered furniture }\end{array}$ \\
\hline Kasiinsa & Celtis zenkeri & $\begin{array}{l}\text { Underutilised at that time. } \\
\text { Recommended for use in most } \\
\text { structural work }\end{array}$ & $\begin{array}{l}\text { Used for furniture } \\
\text { Not common in the source } \\
\text { forest and consequently on } \\
\text { the market }\end{array}$ \\
\hline Mpewere & Piptadeniastrum African & $\begin{array}{l}\text { Not very decorative. } \\
\text { Good for furniture }\end{array}$ & $\begin{array}{l}\text { Originally undesired } \\
\text { because of the pungent } \\
\text { /chocking smell } \\
\text { Used with stress and makes } \\
\text { good furniture }\end{array}$ \\
\hline Sadrela & Cedrella odorata & Not documented & \\
\hline Mutuba & Ficus natalensis & $\begin{array}{l}\text { Not documented and not given } \\
\text { attention }\end{array}$ & $\begin{array}{l}\text { Used to make framings for } \\
\text { upholstered furniture }\end{array}$ \\
\hline Namagulu & Musanga cecropioides & $\begin{array}{l}\text { Susceptible to borers } \\
\text { Used for boxes and crates }\end{array}$ & $\begin{array}{l}\text { Frames } \\
\text { furniture. }\end{array}$ \\
\hline Mukokoowe & Ficus ovate & Not mentioned & $\begin{array}{l}\text { Frames of upholstered } \\
\text { furniture } \\
\text { Has sap that helps hold nails } \\
\text { firmly on drying }\end{array}$ \\
\hline Settaala & Polyscias ferruginea & $\begin{array}{l}\text { Not recommended for strength } \\
\text { desired structures }\end{array}$ & $\begin{array}{l}\text { Used for face boards and } \\
\text { ceilings framework }\end{array}$ \\
\hline Musambya & Markhamia lutea & $\begin{array}{l}\text { Used for small section area jobs like } \\
\text { door and window frames. Many } \\
\text { household items. }\end{array}$ & $\begin{array}{l}\text { Use for wide surface now } \\
\text { especially table tops along } \\
\text { Ggaba road,in Kampala. }\end{array}$ \\
\hline Cypres & Cupressus lusitanica & $\begin{array}{l}\text { Provides good quality joinery and } \\
\text { furniture timber if processed well } \\
\text { and not young(immature) }\end{array}$ & $\begin{array}{l}\text { Not used earlier because it } \\
\text { was very knotty and its } \\
\text { timber was young (more } \\
\text { sapwood than heartwood). } \\
\text { Now good for bright } \\
\text { furniture furnishers }\end{array}$ \\
\hline Mugavu & Albizia coriaria & High quality furniture timber. & $\begin{array}{l}\text { Very common and cheap } \\
\text { and heavy by weight to meet } \\
\text { customers desires. Never } \\
\text { dries by air-drying unless } \\
\text { kiln dried. }\end{array}$ \\
\hline Lufugo & Celtis mildbraedii & $\begin{array}{l}\text { Underutilised with potential for high } \\
\text { strength construction }\end{array}$ & $\begin{array}{l}\text { Very available for especially } \\
\text { partitioning and frame } \\
\text { construction }\end{array}$ \\
\hline Muwafu & Canarium schweinfurthii & $\begin{array}{l}\text { For plywood and shuttering } \\
\text { Woolly and un desirable timber } \\
\text { finishes }\end{array}$ & $\begin{array}{l}\text { Used for making good } \\
\text { finishes of shop shelves. } \\
\text { Originally undesired for } \\
\text { being waxy and troublesome } \\
\text { while machining. }\end{array}$ \\
\hline Mukusi & Uapaca guineense & Splits and bores poorly. & $\begin{array}{l}\text { Makes good parquet boards } \\
\text { with a good pink-brown } \\
\text { decorative finish }\end{array}$ \\
\hline Nkuzannyana & Blighia stipulosa & $\begin{array}{l}\text { Not easily obtained in large sizes } \\
\text { with fair finishing qualities }\end{array}$ & $\begin{array}{l}\text { Not originally obtained } \\
\text { because of traditional ties } \\
\text { and medicinal values } \\
\text { Now seldom used for } \\
\text { shutters and coffee sets }\end{array}$ \\
\hline Nzingu & Hallea stipulosa & $\begin{array}{l}\text { Good finishes giving high grade } \\
\text { products }\end{array}$ & $\begin{array}{l}\text { Often get scarce on the } \\
\text { markets, but used well for } \\
\text { making high } \text { quality } \\
\text { furniture }\end{array}$ \\
\hline Kabakanjagala & Aleurites moluccana & Not documented & $\begin{array}{lcc}\text { Makes frames } & \text { for } \\
\text { upholstered furniture } & \\
\end{array}$ \\
\hline
\end{tabular}




\section{Timber Management Practices in Furniture Workshops}

Timber Storage: Only 31\% of the workshops visited had storage space and/or timber stores. As a result the majority $(69 \%)$ of the carpenters kept enough timber for a given task at a time. This was an indicator that the carpenters did not pay attention to timber conditioning prior to its use.

Quality of Timber Stacks: Majority (67\%) of the furniture workshops did not have timber stacks. Only $3 \%$ of the stores had well-stacked timber and for the rest, the stacks were either poorly arranged or the timber was just piled up (Table 5 and Fig. 1).

Table 2. Quality of Timber Stacks.

\begin{tabular}{lc}
\hline Status of timber stack & Percent $(\mathbf{N}=\mathbf{1 0 0})$ \\
\hline Pile & 26 \\
Well stacked & 3 \\
Poorly stacked & 4 \\
No timber at all & 67 \\
\hline
\end{tabular}

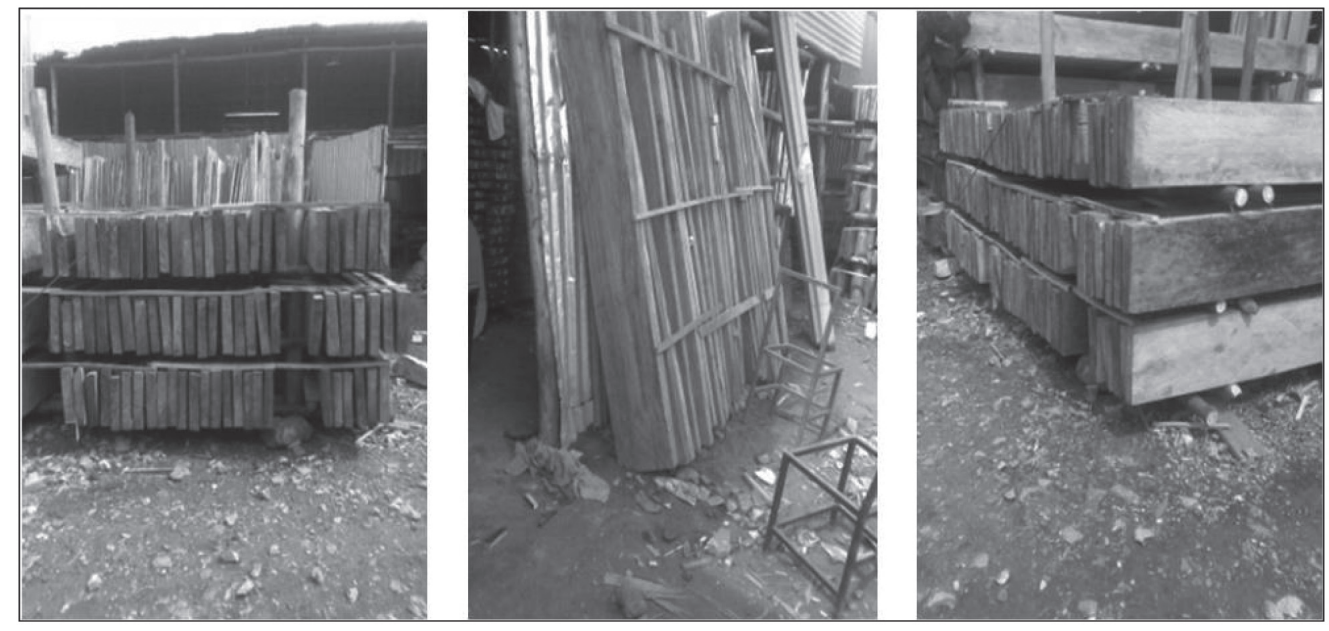

Figure 1. Improper timber stacks in carpentry workshops at Bwaise, Kampala District.

Timber Seasoning: There was only limited timber seasoning observed and majority (95\%) of the small scale furniture workshops did not have any seasoning technology apart from air seasoning. None of the workshops did kiln seasoning. As a result, most of the timber at the various workshops had moisture content ranging between $31 \%$ and $35 \%$ with only $3 \%$ of the timber in the workshops having moisture contents below $12 \%$ (Fig. 2). 


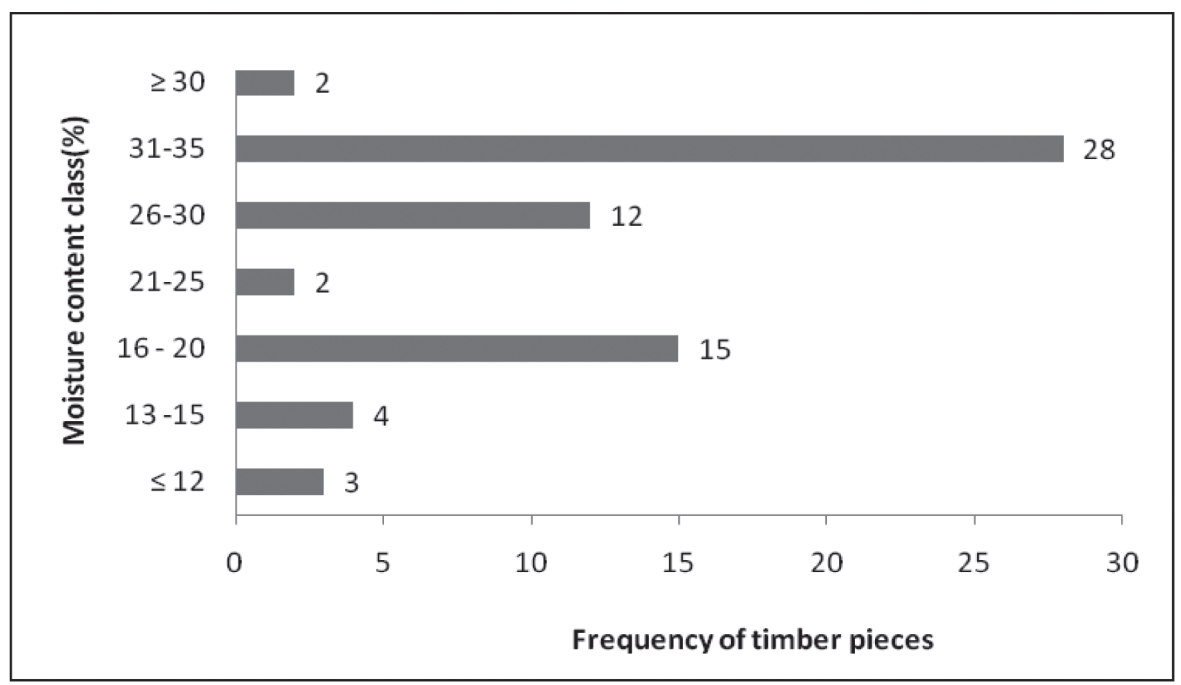

Figure 2. Moisture content of the timber in furniture workshops.

Product Storage: About $45 \%$ of the carpentry workshops had no designated product sheds and the finished timber products were left exposed to the open environment all day and night. 17\% of the workshops had designated indoor storage areas while 34\% exposed the timber products to open environment during the day only (Fig. 3 and Fig. 4).

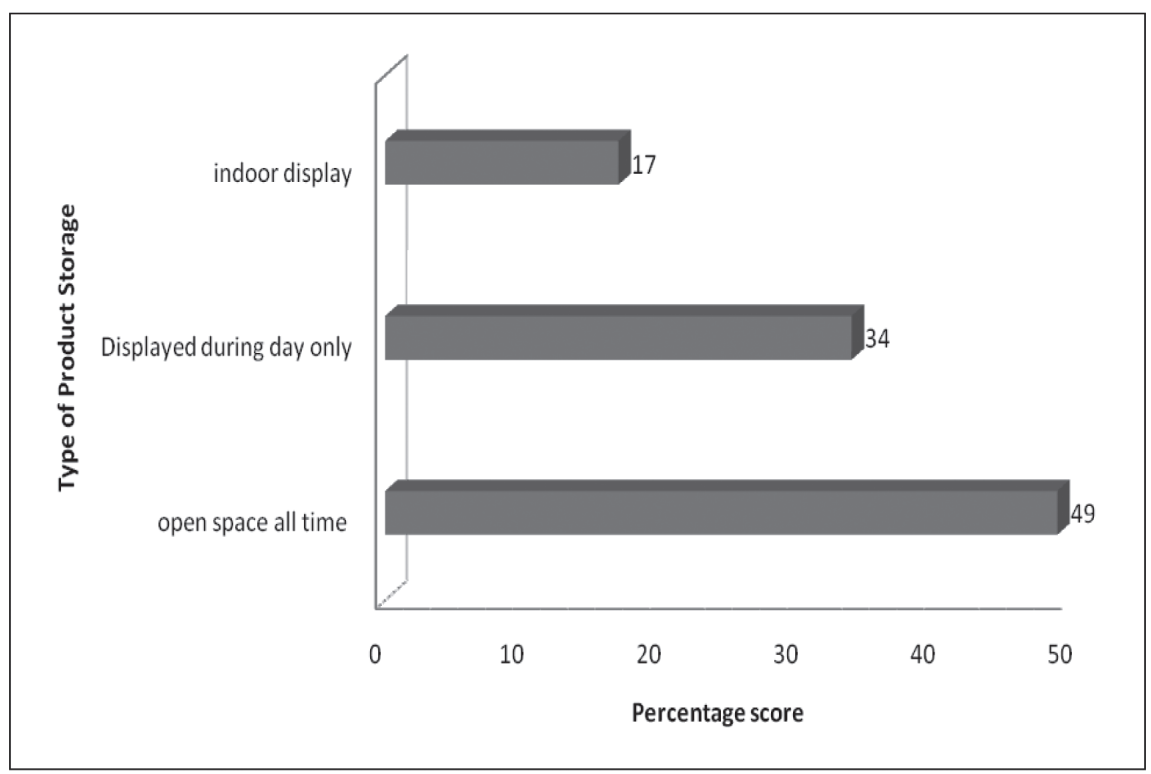

Figure 3. Product storage in carpentry workshops 


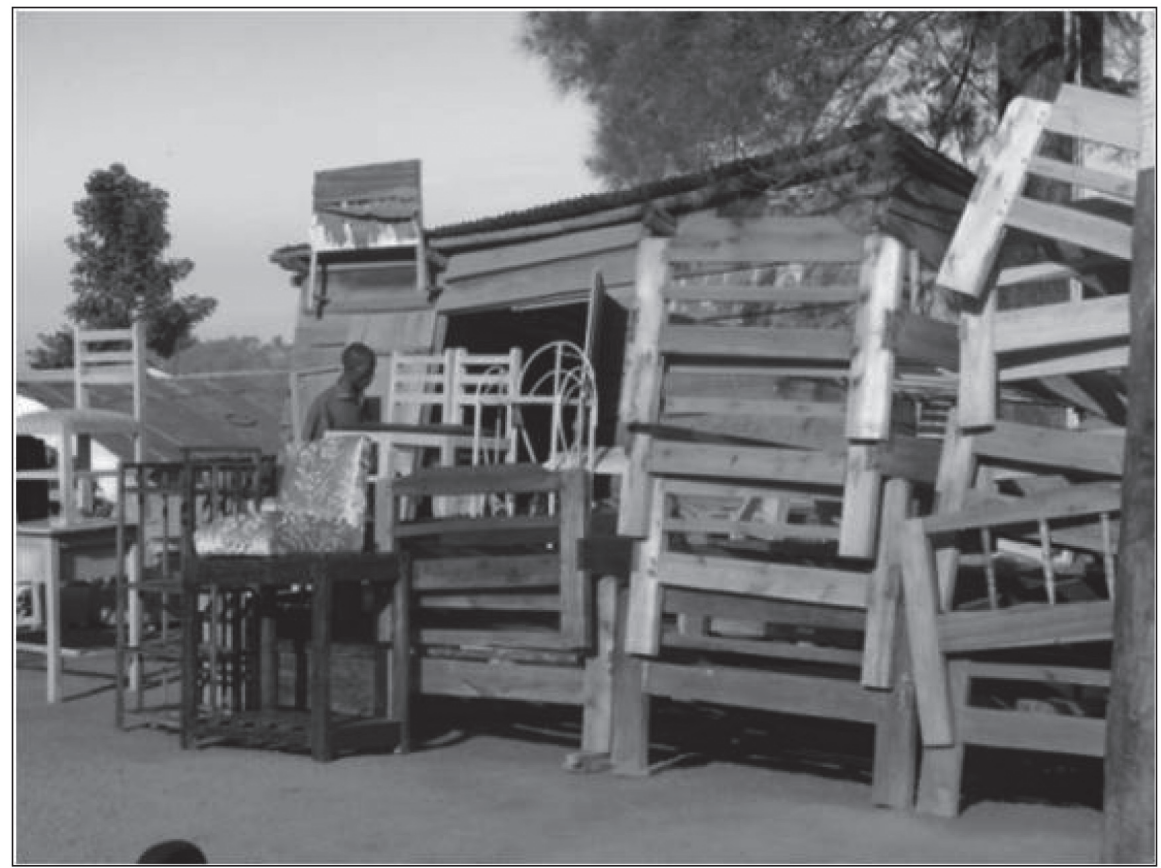

Figure 4. Timber products exposed at a furniture workshop.

Waste Management: Shavings and off-cuts were the most common types of waste; sawdust and rejects scored lower (Fig. 5). Wood shavings, off-cuts and sawdust were inappropriately managed yet they could be utilised for several applications as raw materials. Most (69\%) furniture workshops did not utilise wood waste; about $22 \%$ burnt it, while $6 \%$ sold it as fuel; only $3 \%$ converted it to useful source of energy for the workshop activities.

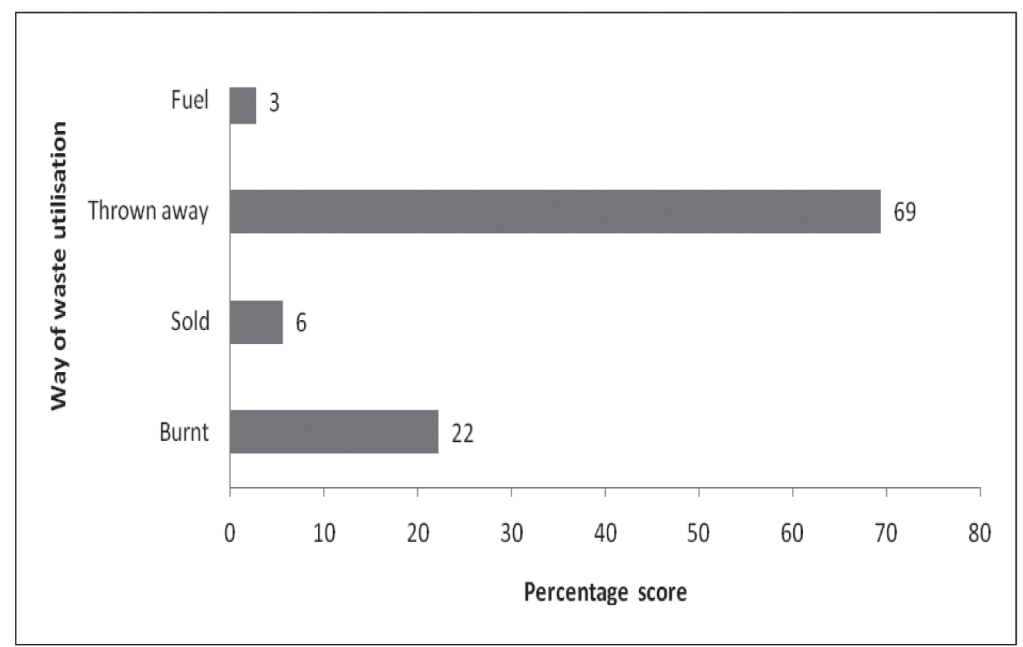

Figure 5. Waste utilisation in carpentry workshops

Timber Grading: Most (97\%) of the respondents reported that they graded timber although the criteria they used were not based on standard procedures. As a control, the researcher obtained the grades of timber found in workshops using statndard grading procedures and rules. The grades of timber used in carpentry workshops are listed in table 6. The timber grades are explained in the Uganda timber grading rules (Tack 1967). 
Table 6. Timber grades in furniture workshops

\begin{tabular}{lc}
\hline Commonest Timber Grade & Percentage occurrence \\
\hline First grade & 17 \\
Second grade & 21 \\
Third grade & 36 \\
No timber store & 26 \\
\hline
\end{tabular}

\section{DISCUSSION}

\section{Commonly Used Timber Species}

The type and frequency of use of timber species in furniture workshops depends on the market forces of demand and supply as noted by Zziwa et al. (2006a). In addition, factors that affect these market forces such as individual tastes and preferences of both carpenters and clients also play a major role in the choice of species. M. excelsa, A. coriaria, M. lutea and C. albidum were the most abundant in the workshops visited probably because they satisfied both the market and had desired properties and characteristics, such as ease to work, as compared to the other species used. The other non traditional timber species were mainly used to make frameworks for upholstered furniture, where they are completely hidden but with a final product that has good decorative appearance but unequally durable. The scarcest timber species were the traditional ones probably because the small scale workshops could not raise substantial financial capital to stock such expensive timbers in their sheds. Stocking such expensive timbers by such low investment firms is a challenge as earlier noted by Auren and Krassowska (2004).

\section{Timber Management Practices}

The generally poor timber management practices could probably be attributed to low levels of education, limited exposure to suitable technologies and limited technical training of workshop personnel in carpentry and joinery practices. Sseremba (2005) noted that only $16 \%$ of the carpenters had training in carpentry and hence were applying proper timber management and processing practices. Auren and Krassowska (2004) also observed low levels of education amongst small scale entrepreneurs which include small furniture workshops.

Raw Material Management: The limited availability of timber storage areas in carpentry workshops could have been caused by a limited space for setting up production lines. Strategies of evading tax also forced some of these carpenters not to have timber storage areas claiming that the timber stores bias Uganda Revenue Authority (URA) officers who end up issuing high tax bills. URA personnel often consider store size and timber stock as an indicator of scale of production, hence the tax charge.

The prevalence of poor timber stacking resulted from the fact that carpenters lacked the appropriate training and hence the prevalence of defective timber as earlier noted by Kityo and Plumpture (1997). The occurrence of limited timber seasoning in furniture workshops is contrary to the basics of timber utilisation. Seasoned timber has protection against biodegrading organisms, gives good machining properties such as sanding and planing, better gluing and finishing properties (Moss 1997). The major reason for use of unseasoned timber was limited skills in seasoning and lack of capital to install appropriate seasoning equipment. According to Auren and Krassowska (2004), kiln technologies are expensive and may not be afforded by small scale furniture workshops due to their low levels of capital investment. Several carpenters that make upholstery frames claimed that wet timber is easily nailed and the nail fastenings hold more when done with wet wood. However, this it is scientifically known that stresses during drying of wet wood components would cause severe distortion (e,g. loosening of nail fastenings and other joints) and would result in failure of the final products (Moss 1997). However, the fact that relatively wet timber is easier to work for some processing activities should not be neglected. 
For example, the energy used for the primary processing of dry eucalyptus wood in such low technology firms is higher than when processed green. The technology available to these firms may not overcome the seasoning defects that may accrue.

Product Management: The finished products were exposed to fluctuations in environmental conditions of direct rain water and excessive heat. This compromised the performance of the products even before they were bought. Poor handling of timber products increases costs in servicing damages both economically and environmentally. Poor product handling increases timber waste that calls for more cutting of trees for replacement (Kambugu et al. 2005).

Waste Management: There was limited utilisation of wastes, yet as noted by Atuhe (2005) improved general recovery of these workshops depends on waste management. In most workshops shavings, off-cuts and sawdust were either sold or burnt. Again this is probably due to the limited knowledge of utilisation of these wastes. Limited skills and technical expertise in the production activities of small scale enterprises were previously reported (Auren and Krassowska 2004).

Grading: A few carpenters who graded their timber did not adequately follow the standard grading procedures as indicated in Tack (1967) probably because of lack of required skill. This resulted in the prevalence of third grade timber, the poorest grade of timber according to the timber grading rules of Uganda (Tack 1967). This is contrary to the requirements of timber for furniture production (Kityo and Plumpture 1997). The reasons for this could have been the low cost of the third grade timbers since the first and second class timbers are often bought at higher prices by the medium and large scale carpentry workshops. The $3^{\text {rd }}$ class visual grade timber, which is commonly used in these workshops, is inappropriate for production of decorative furniture because it has higher incidence of defects and requires costly processing in order to obtain a product of relatively good quality.

\section{CONCLUSIONS}

The study revealed that more non traditional timber species were available on the market as compared to the traditional timber species. Most traditional timber species were categorised as scarce species since their supply is low. The timber management practices were generally poor, being characterised by lack of timber storage areas, poor timber stacking methods, limited seasoning, absence of sheltered displays for products, burning and throwing away the waste, improper grading of timber and uncontrolled use of poor grade timber.

Government and the private sector should increase afforestation of the listed common, nontraditional and scarce species so as to diversify raw materials for furniture making tasks. In addition, institutionalisation and formalisation of furniture workshops' activities should be done to improve jurisdiction and monitoring the timber management activities prior to certification. Studies aimed at improving properties of the non traditional species listed should be undertaken Prospects of wood carving should as well be studied so as to improve timber utilisation in small scale furniture workshops and introduce new designs distinctive to Uganda. This could create international market interest in the furniture due to their unique appearance reflecting the country culture and tradition. Above all, research on the effectiveness and performance of trading groups and cooperatives amongst furniture workshops should be conducted. 


\section{ACKNOWLEDGEMENTS}

We acknowledge the funding from the Norwegian Agency for Development Co-Operation (NORAD). We also appreciate the contributions by the staff of Makerere University in the Faculty of Forestry and Nature Conservation and the Faculty of Technology.

\section{REFERENCES}

Atuhe, G. 2005. Determination of recovery in furniture workshops. A case of Constra Works Ltd, Entebbe. BSc dissertation, Faculty of Forestry and Nature Conservation, Makerere University, Kampala, Uganda (Unpublished).

Auren, R.; Krassowska, K. 2004. Small and medium forest enterprises Uganda. Forestry Inspection Division. International Institute of Environment and Development. London, UK. 73p.

DSM, Department of Statistics-Malysia. 2002. Furniture Export Data. Department of Statistics Malaysia, Malaysia. 24p

Kambugu, R.K.; Banana, A. Y.; Kaboggoza, J. R. S.; Zziwa, A.; Agea, J. G. 2005. Relative efficiency of sawmill types operating in Uganda's softwood plantations. Uganda Journal of Agricultural Sciences 11(1): 14-19.

Kityo, P.W.; Plumpture, R. A. 1997. The Uganda Timber Users Handbook. Common Wealth Secretariat, London. UK. 78p.

Moss, P. J. 1997. Multiple-bolted joints in wood members: a literature review. Gen. Tech. Rep. FPL-GTR-97. Madison, WI: U.S. Department of Agriculture, Forest Service, Forest Products Laboratory. $18 \mathrm{p}$.

Mugabi, P. 2002. Assessment of human impacts and potential uses of the underutilised timber species in Budongo forest Reserve, Uganda. Msc thesis. Agricutural University of Norway (Un-published).

Sseremba, O. E. 2005. Tree species used in the furniture industry in Uganda-Masaka District. BSc Dissertation. Faculty of Forestry and Nature Conservation. Makerere University. Kampala, Uganda (Un-published).

Tack, C. H. 1967. Uganda Timbers; A list of the more common Uganda Timbers and their properties. Government Printery, Entebbe, Uganda.

UBOS, Uganda Bureau of Statistics. 2002. A report on the Uganda Business Register 2001/2002. Kampala, Uganda. 53p

UN, United Nations. 2006. The Millennium Development Goals report. New York. USA. 34-39.

Zziwa, A.; Bukenya, M.; Sseremba, O. E.; Kyeyune, R.K. 2006a. Non-traditional tree species used in the furniture industry in Masaka District, central Uganda. Uganda Journal of Agricultural Sciences 12(1): 29 -37 ISSN 1026-0919. 
Zziwa, A.; Kaboggoza, J. R. S.; Mwakali, A.; Banana, A. Y.; Kyeyune, R. K. 2006b. Physical and Mechanical Properties of Some Less Utilised Tropical Timber Tree Species Growing in Uganda. Uganda Journal of Agricultural Sciences 12(1):29-37 